Vol. 3, No. 2, 2020

\author{
A. N. Kucherenko ${ }^{1}$, S. O. Mankevych ${ }^{1}$, M. Ya. Kuznetsova ${ }^{2}$, V. S. Moravskyi ${ }^{1}$ \\ Lviv Polytechnic National University, \\ ${ }^{1}$ Department of Chemical Technology of Plastics Processing, \\ ${ }^{2}$ Department of Heat Engineering and Thermal and Nuclear Power Plants \\ vmoravsky@gmail.com
}

\title{
PECULIARITIES OF METALIZATION OF PULLED POLYETHYLENE
}

https://doi.org/10.23939/ctas2020.02.140

The results of experimental studies of the peculiarities of metallization of granular polyethylene are presented. The influence of concentration factors on the metallization process of zinc-activated polyethylene granules of brand Liten PL-10 was investigated. It is established that by changing the concentration of copper sulfate and sodium hydroxide, as well as the degree of loading of polymeric raw materials, it is possible to effectively regulate the amount of recovered copper on granules of polyethylene, and therefore the thickness of the metal layer formed on them. The use of the method of preliminary processing of activated polyethylene granules in a solution of copper sulfate can significantly reduce the induction period and increase the rate of recovery of copper ions.

Key words: composite, polyethylene, copper, zinc, chemical metallization, kinetics.

\section{Introduction}

Considering new trends in the field of environmental protection and the adopted Council Directive Of European Union on the prohibition of the use of disposable plastics [1], significant release of polymeric raw materials used in this field can be expected. This particularly applies to polymers such as polyethylene, polypropylene, polystyrene and its derivatives traditionally used in the manufacture of disposable tableware and packaging products. Among the listed polymers for polyethylene, which main area of use is in particular production of the film, the adopted directive means the loss of the main area of use. Thus, the introduction of polyethylene into new and uncharacteristic uses is promising, given the large capacity of its production and low cost. This can be achieved by creating new composite materials based on it.

Composite materials allow to obtain the necessary combination of properties: high specific strength and hardness, heat and wear resistance, heat-protective properties, etc. Composite materials have been widely used in recent years as high-tech structural materials [2]. Their use makes it possible to create previously unavailable, fundamentally new construction designs. Thanks to the composite materials, a new qualitative leap in increasing the power of engines, reducing the mass of parts and structures and increasing the weight efficiency of vehicles and aerospace vehicles has become possible
[3]. Composite materials play an increasingly important role in the industry and are now the leaders in practical use due to high technological effectiveness and scientific intensity, excellent combination of properties such as high specific modulus and strength, wear resistance, high abrasion resistance, improved properties at higher temperatures, etc. makes them most applicable [4] in various engineering fields such as aviation, military, transport and construction [5].

The perspective field of composite materials use can be considered non-traditional energy, in which the composite materials, in addition to widespread use as structural materials, can also be used as the active substance, for example in heat accumulators [6]. The use of phase-transition materials heat such as highly crystalline polyethylene [7] in such batteries enables high specific values of energy storage. In this case, to obtain highly efficient heat storage systems, one technological problem must be solved, namely to increase the thermal conductivity values, which are very low for polymers. In this direction, it is promising to create metal-filled polymer composites.

Metal-filled polymer composites are of great interest for obtaining products characterized by thermal and electrical conductivity, certain magnetic properties, and at the same time have low mass and high technological effectiveness [8, 9]. Such materials are processed into products by highly 


\section{Peculiarities of metalization of pulled polyethylene}

productive methods of the polymer processing industry and at the same time they can have electrical conductivity that is close to the conductivity of metals [10]. Improving the performance properties of polymer composites can be achieved by using submicron or nanosized metal particles as fillers [11]. However, in this case, the main problem for obtaining metal-filled composites characterized by high performance properties is the poor dispersion of the metal filler in the polymer matrix. Obtaining homogeneous polymer blends can be achieved using certain technological techniques, in particular, surface modification of the filler [12]. The shape of the metal filler used also has a significant effect on the properties of the final material, with the advantage being that the filler is in the form of short fibers, scales or other long forms [13].

High-tech metal-filled polymer composites can also be obtained using the method of metallization of granular $[14,15]$ or powdered [16-19] polymeric raw materials. This method allows to refuse the stage of pre-mixing the polymer with a metal filler and combine the optaining of the composite with the molding of the final product in one technological process.

Thus, research aimed at obtaining high-tech polymer composites using new technological techniques is promising given the possibility of obtaining materials with a complex of unique properties, which will allow them to be introduced into new and promising fields of use.

\section{Materials and methods of the study}

Granular polymeric raw material used for research is polyethylene brand Liten PL-10 (Unipetrol). Components of chemical reduction solutions [14-18] were: $\mathrm{CuSO}_{4} \cdot 5 \mathrm{H}_{2} \mathrm{O}$ brand "pure for analysis", EDTA- $\mathrm{Na}_{2} \quad\left(\mathrm{C}_{10} \mathrm{H}_{14} \mathrm{~N}_{2} \mathrm{Na}_{2} \mathrm{O}_{8} \cdot 2 \mathrm{H}_{2} \mathrm{O}\right)$ brand "pure for analysis", $\mathrm{NaOH}$ brand "pure", formalin stabilized.

Activation of the polyethylene surface was conducted according to the developed method [19] using ball mill and fine zinc as the activator metal. The ratio of the activator metal and polyethylene (PE) was $\mathrm{Zn}: \Pi \mathrm{E}=9: 50$ (mass parts).

Investigation of kinetic regularities of copper recovery on activated polyethylene was performed by volumetric method by the amount of hydrogen released $[16,18]$.

\section{Results of the studies and their discussion}

In order to obtain high-quality polymeric raw materials and to understand the processes that occur during the recovery of copper, it is necessary to know the basic patterns of formation of a metal layer on the activated polyethylene surface. To this end, the kinetics of metal layer formation in chemical precipitation solutions was investigated.

The analysis of the kinetic curves obtained shows that the greatest influence on the copper recovery rate has the concentration of copper sulfate and sodium hydroxide, the effect of the concentration of EDTA-Na $\mathrm{Na}_{2}$ is negligible. An increase in the concentration of both copper sulfate and sodium hydroxide affects some increase in the rate and amount of recovered copper (Fig. 1), with the effect of the concentration of copper sulfate being more significant.

It should be noted that in all cases, regardless of the concentration of components, there is a fairly significant induction period (2-5 min) after which the reaction occurs at almost constant speed and ends at the consumption of copper sulfate, which can be judged by the loss of coloring solutions, which occurs simultaneously with the termination of hydrogen evolution. The existence of an induction period is probably caused by the processes of wetting the activated polymer surface with a chemical reduction solution, which is a necessary condition for ensuring contact between the components and undergoing a chemical reaction, as well as the fact that the activation occurs as a result of the interaction with zinc, which passes without hydrogen evolution.

In order to reduce the duration of the induction period and to improve the efficiency of the metallization process, studies were conducted aimed at establishing the possibility of its reduction. Based on the assumption that the induction period caused by the surface wetting process it was supposed to wet the polymer surface by treating activated polyethylene granules with distilled water before conducting the metallization process. Such a solution proved to be ineffective and shortening of the induction period was not observed (Fig. 2a pos. 2). Use of $\mathrm{CuSO} 4$ solution instead of distilled water for wetting proved to be more effective (Fig. 2a pos. 3) in this case the reduction the duration of the induction period by more than 3 times.

In addition, it should be noted that the wetting processes still have some effect on the duration of the induction period, as can be judged from the fact that the use of pre-metallized polyethylene granules and metallized polyethylene granules moistened in 


\section{A. N. Kucherenko, S. O. Mankevych, M. Ya. Kuznetsova, V. S. Moravskyi}

distilled water as raw materials affects the different duration of induction period (Fig. 2a pos. 4 and 5). In this case, it is possible to completely reject the stage of activation of the recovery of copper by zinc, which occurs without the release of hydrogen. Recovery of copper ions occurs only as a result of the autocatalytic reaction of interaction with copper. The pre-moistened surface provides rapid access of the chemical recovery solution reagents to the copper of the surface and reduces the duration of the induction period.

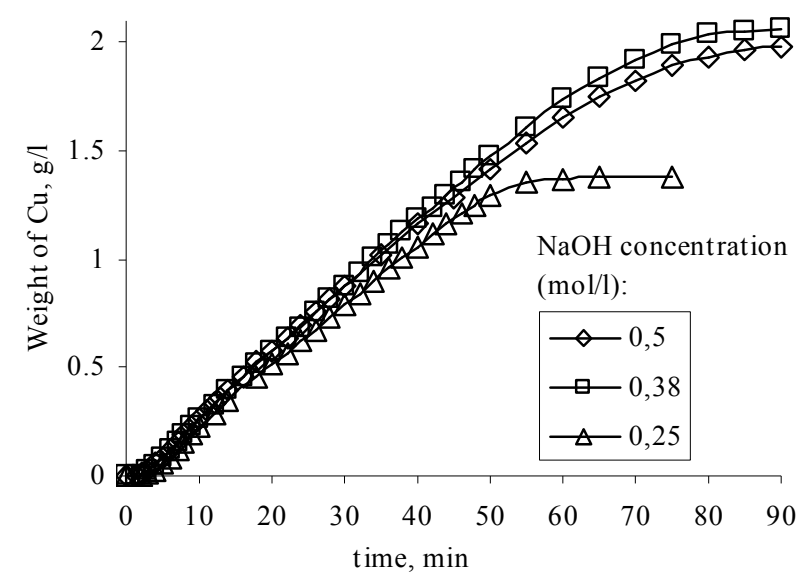

$a$

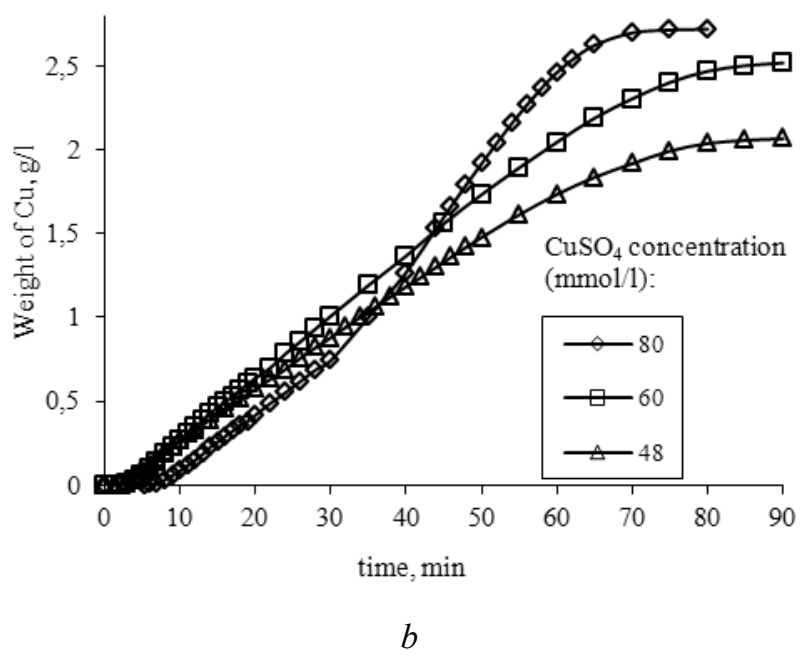

Fig. 1. Kinetic curves of recovery of copper ions on the activated surface of polyethylene granules. Concentration $(\mathrm{mol} / \mathrm{l})$ :

a) $\mathrm{CuSO}_{4}-0,5 ; \mathrm{EDTA}-\mathrm{Na}_{2}-0,67$; formaldehyde - 3,7.

b) $\mathrm{NaOH}-0,38$; EDTA-Na $-0,67$; formaldehyde - 3,7.

Thus, it can be argued that a reduction in the duration of the induction period and an increase in metallization efficiency can be achieved by using a copper sulfate solution. The effectiveness of such a solution becomes even more significant in the case of chemical reduction solutions with higher concentrations of $\mathrm{CuSO}_{4}$ (Fig. 2b), for which the reduction of the duration of the induction period is more than 6 times.

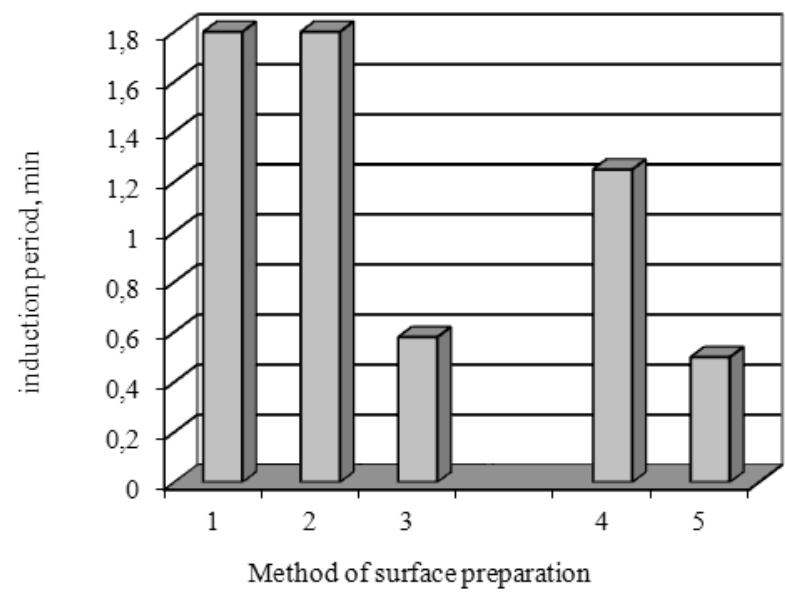

$a$

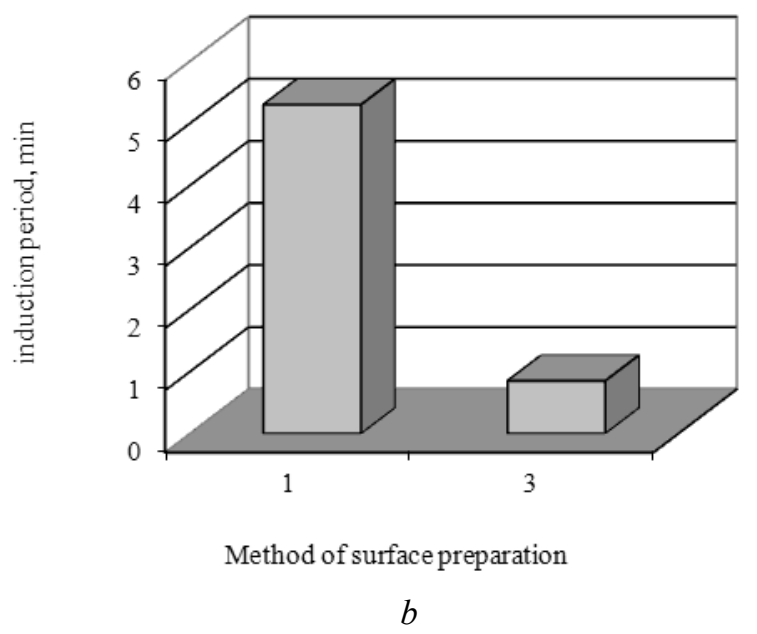

Fig. 2. The influence of the method of preparation of the activated polyethylene surface on the duration of the induction period of the recovery of copper ions. Concentration (mol/l): a) $\mathrm{CuSO}_{4}-0,5 ; \mathrm{EDTA}-\mathrm{Na}_{2}-0,67$; $\mathrm{NaOH}-0,38$; formaldehyde - 3,7. b) $\mathrm{CuSO}_{4}-0,8$; EDTA-Na $-0,67 ; \mathrm{NaOH}-0,38$; formaldehyde - 3,7. 1 - the original activated polyethylene,

2 - the original activated polyethylene moistened in distilled water, 3 - the original activated polyethylene moistened in $\mathrm{CuSO}_{4}$ solution, 4-metallic granules of polyethylene, 5 - metallic granules of polyethylene moistened in distilled water.

As it was established during the research, the method of preparation of the activated surface also has a significant effect on the rate of recovery of copper ions in the solution of chemical metallization (Fig. 3). 


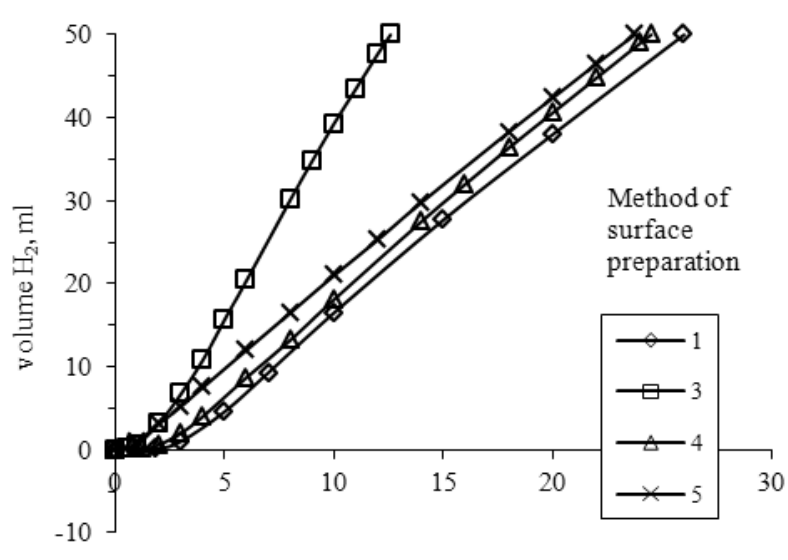

time, $\min$

Fig. 3. The influence of the method of preparation of the activated surface of polyethylene on the rate of hydrogen evolution. Concentration (mol/l):

$\mathrm{CuSO}_{4}-0,5 ; \mathrm{EDTA}-\mathrm{Na}_{2}-0,67 ; \mathrm{NaOH}-0,38$; formaldehyde $-3,7$.

In the case of using the original granules of activated polyethylene (1), metallized granules of polyethylene (4) and metallized granules of polyethylene moistened in distilled water (5), the rate of copper recovery reaction is almost the same. When using activated polyethylene wetted by in $\mathrm{CuSO}_{4}$ solution (3), we observe the highest rate of recovery of copper ions. This can be explained by the high activity of copper particles formed by the interaction with zinc in $\mathrm{CuSO}_{4}$ solution. It can also be argued that as a result of the treatment of activated polyethylene in $\mathrm{CuSO}_{4}$ solution only a partial interaction of zinc with copper ions occurs, as evidenced by the limiting amount of recovered metal, which we determine by the amount of hydrogen released (Table 1) by the reaction:

$$
\begin{aligned}
& 2 \mathrm{CH}_{2} \mathrm{O}+\mathrm{Cu}^{2+}+4 \mathrm{OH}^{-} \rightarrow \\
& \rightarrow \mathrm{Cu} \downarrow+\mathrm{H}_{2} \uparrow+2 \mathrm{HCOO}^{-}+2 \mathrm{H}_{2} \mathrm{O} .
\end{aligned}
$$

In the case of pre-metallized polyethylene granules (4), the amount of recovered copper as a result of the interaction with formaldehyde is highest. This result is expected because the use of such raw materials does not involve the exchange reaction with zinc, which increases the amount of copper recovered as a result of interaction with formaldehyde. The specific contribution of zinc exchange reaction to the copper recovery process can be illustrated by the example of the original activated granules (1) and activated granules and machined in $\mathrm{CuSO}_{4}$ solution (3). In this case, we have less copper recovered as a result of the interaction with formaldehyde. Also practically equal amounts of recovered copper indicate that no deep transformations between zinc and copper ions occur in the preparation of the granules in $\mathrm{CuSO}_{4}$ solution. Thus, it can be argued that the nature of the activation remains unchanged, but the high surface activity after its processing in $\mathrm{CuSO}_{4}$ solution can significantly increase the rate of recovery of copper ions, which improves the efficiency of the metallization process.

Table 1

The dependence of the limit amount of recovered copper on the method of preparation of the activated surface of polyethylene

\begin{tabular}{|c|c|c|}
\hline \multicolumn{2}{|c|}{ Method of surface preparation } & $\begin{array}{c}\text { Weight of recovered } \\
\text { copper, } \mathrm{g} / 1\end{array}$ \\
\hline 1 & $\begin{array}{c}\text { the original activated } \\
\text { polyethylene }\end{array}$ & 2,06 \\
\hline 3 & $\begin{array}{c}\text { the original activated } \\
\text { polyethylene moistened } \\
\text { in solution } \mathrm{CuSO}_{4}\end{array}$ & 2,04 \\
\hline 4 & $\begin{array}{c}\text { metallized polyethylene } \\
\text { granules }\end{array}$ & 2,35 \\
\hline
\end{tabular}

Along with the influence of the concentration factors of the components of chemical metallization solutions on the kinetic regularities of metallization of granular polyethylene, the effect of the ratio of activated polymeric raw material - chemical recovery solution, ie the influence of the degree of raw material loading on the kinetic regularities of metallization (Fig. 4) was also investigated.

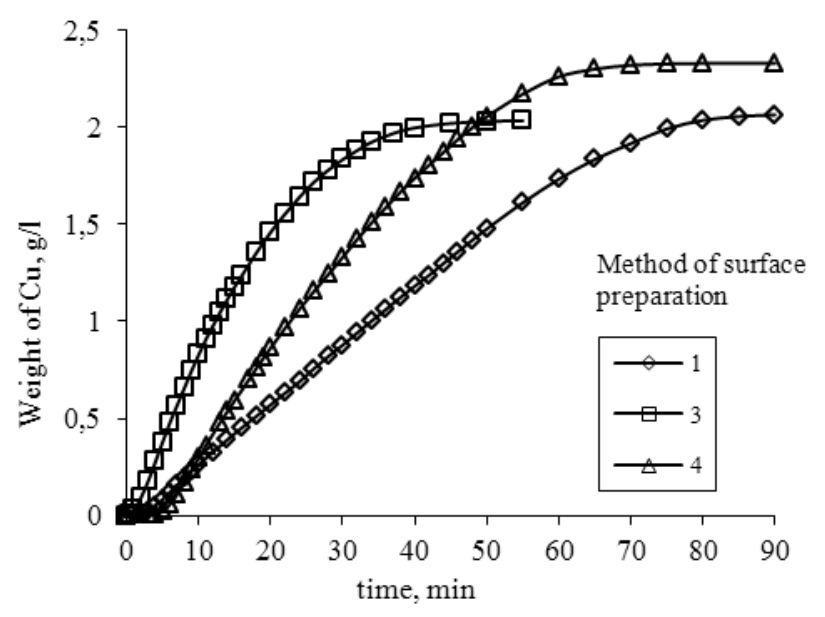

Fig. 4. Effect of loading of activated polyethylene granules on kinetic curves of copper ion recovery. Concentration (mol/l): $\mathrm{CuSO}_{4}-0,5 ; \mathrm{EDTA}-\mathrm{Na}_{2}-0,67$; $\mathrm{NaOH}-0,38$; formaldehyde $-3,7$ 


\section{A. N. Kucherenko, S. O. Mankevych, M. Ya. Kuznetsova, V. S. Moravskyi}

The analysis of the obtained dependences of the influence of the degree of loading of activated polyethylene granules on the kinetic curves of copper ion recovery shows that this factor is one of the most significant. By changing the ratio of the original polymeric raw material - a solution of chemical metallization can effectively affect the speed of the recovery process. This feature is technologically convenient and can be recommended for use to regulate the metal content of the metallized raw material obtained, and thus to influence the properties of the finished metal-filled composites.

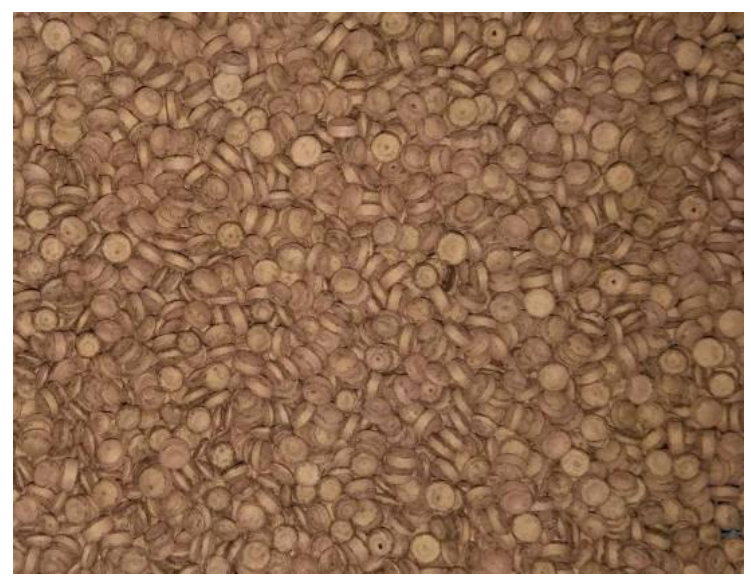

Fig. 5. Photos of metallized granules of polyethylene brand Liten PL-10

The obtained metallized granules are evenly coated with metal (Fig. 5), which during their subsequent processing will allow to obtain metalfilled polymer composites with even distribution of metal in the polymer matrix. In this case, the distribution of metal in the polymer matrix will occur at the stage of direct formation of the product, which will exclude a separate operation of mixing the polymer with a metal filler.

\section{Conclusions}

Thus, studies of the kinetic regularities of the recovery of copper ions in solutions of chemical metallization on activated pellets of polyethylene brand Liten PL-10 suggest that the proposed technology can be used to obtain high quality metallized raw materials with high efficiency and in controlled modes. It is established that the main factors influencing the process of obtaining metallized polyethylene are the concentrations of copper sulfate, sodium hydroxide, the degree of loading of activated polymeric raw materials, as well as the method of preparation of the activated surface.

\section{References}

1. European Council. Council of the European Union (2019). Press releases: Council adopts ban on single-use plastics. Retrieved from https://www.consilium.europa.eu/ en/press/press-releases/2019/05/21/council-adopts-banon-single-use-plastics/

2. Yadav, S., Gangwar, S., Singh, S. (2017). Micro/Nano Reinforced Filled Metal Alloy Composites: A Review Over Current Development in Aerospace and Automobile Applications. Materialstoday: Proceedings, 4(4), 5571-5582. doi:10.1016/j.matpr.2017.06.014

3. Pinto, G., Jimenez-Martin, A. (2001). Conducting aluminum-filled nylon 6 composites. Polymer Composites, 22(1), 65-70. doi: 10.1002/pc.10517

4. Gangwar, S., Yadav, S. (2017). A Review on Mechanical and Tribological Properties of Micro/Nano Filled Metal Alloy Composites. Materialstoday: Proceedings. 4(4), 5583-5592. doi: 10.1016/j.matpr.2017.06.015

5. Sharma, S., Sudhakara, P., Nijjar, S., Saina, S., Singh, G. (2018). Recent Progress of Composite Materials in various Novel Engineering Applications. Materialstoday: Proceedings. 5(14), 28195-28202. doi: 10.1016/j.matpr.2018.10.063

6. Chavan, S., Gumtapure, V., Perumal, A. (2020). Numerical and experimental analysis on thermal energy storage of polyethylene/functionalized graphene composite phase change materials. Journal of Energy Storage. 27, 101045. doi: 10.1016/j.est.2019.101045

7. Navarro, L., Barreneche, C., Castell, A., Redpath, D., Griffiths, P., Cabeza, L. (2017). High density polyethylene spheres with PCM for domestic hot water applications: Water tank and laboratory scale study. Journal of Energy Storage. 13, 262-267. doi: 10.1016/j.est.2017.07.025

8. Pinto, G., Maidana, M. B. (2001). Conducting polymer composites of zinc-filled nylon 6. Journal of Applied Polymer Science. 82(6), 1449- 1454. doi: 10.1002/app.1983

9. Mamunya, Y. P., Davydenko, V. V., Pissis, P., Lebedev, E. V. (2002). Electrical and thermal conductivity of polymers filled with metal powders. European polymer journal. 38(9), 1887-1897. doi: 10.1016/S00143057(02)00064-2

10. Tanaka, T., Montanari, G. C., Mulhaupt, R. (2004). Polymer nanocomposites as dielectrics and electrical insulationperspectives for processing technologies, material characterization and future applications. IEEE Transactions on Dielectrics and Electrical Insulation. 11(5), 763-784. doi: 10.1109/TDEI.2004.1349782

11. Pukánszky, B. (2005). Interfaces and interphases in multicomponent materials: past, present, future. European Polymer Journal. 41(4), 645-662. doi: 10.1016/j.eurpolymj.2004.10.035

12. Nurazreena, Luay Bakir Hussain, Ismail, H., Mariatti, M. (2006). Metal filled high density polyethylene composites - electrical and tensile properties. Journal 


\section{Peculiarities of metalization of pulled polyethylene}

of Thermoplastic Composite Materials. 19(4), 413-425. doi: 10.1177/0892705706062197

13. Bielikov S. B. Volchok I. P. Mitiaiev O. A. Pleskach V. M. Savchenko V. O. (2017). Kompozytsiini materialy v aviabuduvanni (ohliad). Novi materialy $i$ tekhnolohii $v$ metalurhii ta mashynobuduvanni. 2, 32-40. Rezhym dostupu: http://nbuv.gov.ua/UJRN/Nmt_2017_2_8

14. Moravskyi V.S. Tymkiv I.A. Bodnarchuk P.T. (2016). Metalizatsiia polivinilkhlorydnoho plastykatu khimichnym vidnovlenniam v rozchynakh. Visnyk $N U$ "Lvivska Politekhnika" Khimiia tekhnolohiia rechovyn ta yikh zastosuvannia”. 841, 405-409. Rezhym dostupu: http://ena.lp.edu.ua:8080/handle/ntb/34483

15. Moravskyi V.S. Kucherenko A.M. Yakushyk I.S. Dulebova L. Harbach T. (2018). Tekhnolohiia metalizatsii hranulovanoi polimernoi syrovyny. Visnyk $N U$ "Lvivska Politekhnika" Khimiia tekhnolohiia rechovyn ta yikh zastosuvannia". 886, 205-212. Rezhym dostupu: http://ena.lp.edu.ua:8080/handle/ntb/43632

16. Moravskyi, V., Dziaman, I., Suberliak, S., Kuznetsova, M., Tsimbalista, T., Dulebova, L. (2017). Research into kinetic patterns of chemical metallization of powder-like polyvinylchloride. Eastern-European Journal of Enterprise Technologies. 4/12(88), 50-57. doi: 10.15587/1729-4061.2017.108462

17. Moravskyi, V., Dziaman, I., Suberliak, S., Grytsenko, O., Kuznetsova, M. (2017). Features of the Production of Metal-filled Composites by Metallization of Polymeric Raw Materials, 2017 IEEE 7th International Conference on Nanomaterials: Applications and Properties (NAP-2017). IEEE. doi: 10.1109/NAP.2017.8190265

18. Moravskyi, V., Kucherenko, A., Kuznetsova, M., Dziaman, I., Grytsenko, O., Dulebova, L. (2018). Studying the effect of concentration factors on the process of chemical metallization of powdered polyvinylchloride. Eastern-European Journal of Enterprise Technologies. 3/12(93), 40-47. doi: 10.15587/1729-4061.2018.131446

19. Moravskyi V.S. Dziaman I.Z. Baran N.M. Kucherenko A.M. Dulebova L. (2017). Doslidzhennia efektyvnosti aktyvatsii poroshkopodibnoho polivinilkhlorydu. Visnyk NU "Lvivska Politekhnika" Khimiia tekhnolohiia rechovyn ta yikh zastosuvannia”. 868, 413418. Rezhym dostupu: http://ena.lp.edu.ua:8080/handle/ $\mathrm{ntb} / 40676$

\section{А. М. Кучеренко ${ }^{1}$, С. О. Манькевич ${ }^{1}$, М. Я. Кузнецова ${ }^{2}$, В .С. Моравський ${ }^{1}$ Національний університет “Львівська політехніка", ${ }^{1}$ кафедра хімічної технології переробки пластмас, ${ }^{2}$ кафедра теплоенергетики, теплових та атомних електричних станцій}

\section{ОСОБЛИВОСТІ МЕТАЛІЗАЦІї ГРАНУЛЬОВАНОГО ПОЛІЕТИЛЕНУ}

Наведено результати експериментальних досліджень особливостей металізації гранульованого поліетилену. Досліджено вплив концентраційних чинників на процес металізації активованих цинком гранул поліетилену марки Liten PL-10. Встановлено, що зміною концентрації сульфату міді і гідроксиду натрію, а також ступенем завантаження полімерної сировини можна ефективно регулювати кількість відновленої міді на гранулах поліетилену, а значить і товщину сформованого на них шару металу. Використання методу попередньої обробки активованих гранул поліетилену в розчині сульфату міді дозволяє суттєво скоротити індукційний період i збільшити швидкість відновлення іонів міді.

Ключові слова: композит, поліетилен, мідь, цинк, хімічна металізація, кінетика. 